\begin{tabular}{|c|c|}
\hline & Asian Social Work Journal (ASWJ) \\
$\substack{\text { ASIAN SOCIAL WORK } \\
\text { JOURAL } \\
\text { (ASW) }}$ & Volume 4, Issue 1, February 2019 \\
& e-ISSN : 0128-1577 \\
& Journal home page: \\
& www.msocialwork.com \\
\hline
\end{tabular}

\title{
Indigenous Peoples, Poverty and the Role of Social Workers
}

\author{
Suradi $^{1}$, Soni Akmad Nulhaqim ${ }^{2}$, Nandang Mulyana², Edi Suharto ${ }^{3}$ \\ ${ }^{1}$ Research and Development Center for Social Welfare, Ministry of Social Affairs of Republic of Indonesia \\ 2Faculty of Social and Political Science, Padjadjaran University, Bandung, Indonesia \\ ${ }^{3}$ Ministry of Social Affairs of Republic of Indonesia \\ Corrrespondence: Suradi (mas.soeradi@yahoo.co.id)
}

\begin{abstract}
Indigenous peoples were placed as second-class citizens, that have fallen behind in all aspects of life than any other citizen. In fact, indigenous people in any country has gained international legal protection through 'the United Nations Declaration the Right of Indigenous People' since 2007. In the entity, within the indigenous peoples, including women and children. The form of response to the declaration, each country develop policies in the form of regulation and followed by action programs targeting indigenous peoples. It has been over 10 years of the declaration proclaimed, but the indigenous peoples still face a lot of problems in the social, cultural, economic, political, legal, land and natural resources; not even the women and their children. This situation requires the presence of a social work profession, in which the role of professional help to acquire rights, improve the quality of life and well-being of indigenous peoples.
\end{abstract}

Key words: indigenous peoples, poverty, social worker

\section{Introduction}

Indigenous peoples as the guardian of some of the region's most biologically diverse in the world. They feel a responsibility for a large number of languages and cultural diversity of the world, and their traditional knowledge has been and continues to be an invaluable something that benefits for the human race (Zukang, 2009). They have the traditional ecological knowledge and contribute to the environmental management, biodiversity conservation and use of natural resources in a sustainable manner (Berkes. Colding and Folke, 2000; Mauro \& Hardison, 2000; Sobrevila, 2008; FAO, 2010; Popova, 2013).

Indigenous peoples have knowledge of disaster mitigation based on the provisions of customary, traditional knowledge wisely in preventing disaster risk reduction and disaster resilience (\& Jha Jha, 2011; Rumbach \& Foley, 2014). They have indigenous knowledge and culture that includes a lot of material and nonmaterial values as traditional resource rights, as recognized in international law (Mauro \& Hardison, 2000; IAIA. 2012; Berkert, Colding, and Folke, 2000). the description above shows the world that indigenous peoples have contributed and major role in human development and environmentally sustainable manner.

An irony, that indigenous peoples until now still continue to expect the country present among them, pay attention, respect and protection of their rights. In connection with that, they struggle commitment 
towards these rights continues to be made by a variety of risks they have to face it. But they could not expect much to parliament that supposedly represents them. As reported in the publication of the United Nations (2012), that the indigenous peoples as social groups living in poverty always slighted or not considered important by politicians, service providers, and policymakers. This is due to the lack of sound political, financial and social capital; and hence experiencing social exclusion, discrimination and human rights violations happening to them (see UN, 2012).

Indigenous People scattered in 90 countries (UN, 2009), with a population of five (5) percent of the world's population, or about 300 million. Presented by Patrinos (2017) of the World Bank, the distribution of the population of indigenous peoples in the world: Southeast Asia amounting to 30 million (10\%), in China amounted to 108 million (36\%), South Asia 36 million (32\%), Switzerland by 25 million (5\%), Africa 21 million (7\%), in Latin America amounted to 24 million (8\%) and in the United States and Canada amounted to 3 million (1\%).

Of these, an estimated 10-15 percent or 30 million - 45 million people live in poverty (Patrinos, 2017), and the poverty is already in the category of extreme poverty or chronic poverty. Besides the poverty, they face problems are relating to the rights that have not been getting attention, respect for and protection of the state. In this context, the presence of social workers highly anticipated to help them obtain their rights (UN, 2010; Gigler, 2009; Zukang, 2009; Velasques, 2007; Calma, 2008; Hulme, Moore \& Shepherd, 2001; CPRC, 2007).

\section{Concepts and Issues Indigenous Peoples}

Social groups that occupy a certain area for generations in the same lineage (homogeneous), has a strong attachment to nature; customary provide very strong influence on the social system, economy, culture, and politics, and have a different way of life to the dominant community (Hamton \& Toms, 2013; Anderson, Schneider \& Kayseas 2008; Fekadu, 2007; UN 2004, 2009; ADB, 2002; 5Dowing .et.al, 2002); and geographically remote (Sudirman, 2018; Walker, Hamilton \& Groth, 2014; Castillo, 2004; Coates, 2004); known as' indigenous peoples.

In these discussions, used the term 'indigenous peoples', which is a term officially used by the United Nations, multilateral agencies and institutions as well as working groups in international forums. The United Nations itself does not impose these terms to member countries, does not give a clear definition of indigenous peoples, and give freedom to each country to construct the definition according to the needs and context of each country. In Indonesia used the term Indigenous Peoples Customary Law and Remote Indigenous Communities (Arizona, 2016; Kleden, 2017; SAFE and AIPP, 2017); Malaysia used the term Orang Asli (Abdullah, Borhan \& Ahmad, 2015); Maori in New Zealand, Aboriginal Peoples in Canada (Cornell, 2006).

The existence of indigenous peoples has gained recognition in international law, namely in the United Nations Declaration on the Rights of Indigenous Peoples (UNDRIP), since 2007. Since the UNDRIP had been proclaimed by various states to enact such regulations in an effort to provide formal recognition by law to the existence of indigenous peoples. Various programs launched by the government and multilateral agencies, such as in education, health, shelter, clean water and economic enterprises (Feiring, 2008; Melendes \& Loenzo, 2014; Islam \& Carlsen, 2015; Morley, 2015).

It has been over 10 years of UNDRIP is implemented, but until now the indigenous people's in all over the world still face the problems in social, cultural, economic, legal, political, natural resources and land. Here are some examples of the reality of the condition of indigenous peoples in some country after proclaimed UNDRIP. Amnesty International (2014) found violence against women in Canada; and discrimination and injustice by most governments in Asia (AIPP, IWGIA and Forum Asia, 2019), including in the Philippines and Indonesia (Rutten, 2016). Access to health services, education and limited employment; and the indicators show, that access to and use of these services remains well below the national average in most countries. 
Women and children of indigenous peoples are often victims of discrimination (ILO, 2011); and victims of violence (Kuokkanen.R 2012). In Mexican, women suffer from dilapidated health quality due to a lack of education, poverty and inadequate medical staff (Loewenberg, 2010); in Bolivia girls and boys are most vulnerable to unqualified education performance and high dropout rate (Jimenez, \& Vera, 2010); and in Peru forced and early marriage, gender-based violence, unwanted pregnancies, and public health services are inadequate (Astrid \& Girard, 2008). In Mexico a higher level of deprivation in social rights for indigenous peoples than for non-indigenous peoples community (Canedo, 2017).

Attention to indigenous peoples, should not be based on their population alone. More than that, that they as citizens of a sovereign state, and has the human rights protected by international law. Attention also needs to be given exclusively for women and children (see UNDRIP, 2007; UNICEF, 2003). This means, that the discussion of indigenous peoples, including the groups of women and children; and this will have implications for social work services are needed.

Complex issues on indigenous peoples show a portrait of the failure of countries to integrate their national program with the rights of indigenous peoples. The Global development paradigm that declared by 189 countries in 2000 is known as the Millennium Development Goals (MDGs) - ended in 2015; does not have a significant impact on problem-solving related to indigenous peoples. Therefore, a rethinking of the concept of development is needed to be aimed at indigenous peoples (UN, 2015; Christie, 2015). Subsequently, in 2015 until 2030 the global agenda was declared by 193 countries, known as the Sustainable Development Goals (SDGs). The academics community needs to oversee the implementation of the agenda firsthand how SDGs with 17 objectives, to bring the significant impacts for the living conditions of indigenous peoples everywhere.

\section{Indigenous Peoples and Poverty}

Poverty is a fundamental problem related to indigenous peoples all over the countries. An estimated, 10-15 percent of indigenous peoples are categorized as poor and very poor (Patrinos, 2017; UNDP, 2010; 2017; UN, 2009; ADB, 2002). On indigenous peoples' poverty is already in the category of extreme poverty (UN, 2010; Gigler, 2009; Zukang, 2009; Velasques, 2007); or chronic poverty is the poverty has been transmitted between generations, and tend to be relatively intractable (Hulme, Moore \& Shepherd, 2001); living under the poverty, feelings the loss of multi-dimension priority aspects in life, such as income, health and education, low levels of social or political material and the marginal assets that last for years in the whole period of the life cycle, or continuous from generation to generation (CPRC, 2007).

To measure extreme poverty, Velsques (2007) determined several variables there are demography, level of education,remoteness, and market, employment status of the head of household, land ownership, livestock, socio-ethnicity, migration and regional development. Indigenous peoples poverty characterized by low health status, low level of education, slums environment and the risk of hunger, which can be explained as follows:

i. Poor health status has a greater risk of affected throat cancer, malnutrition, and high morbidity and mortality (Vera, 2007; FAO, 2010; Hall \& Petranos, 2011; 2015; Dhir, 2015). Poor health status, especially on women, children, and adolescents. This is due to the limited indigenous peoples accessing health services, such as goods and others health facilities, including medicines, clean water, sanitation, and inadequate the number of health workers trained (Calma, 2008; Islam and Sheikh, 2010; Heineke \& Edward, 2012; UN, 2014; Valeggia \& Snodgrass, 2015; Reading \& Wein, 2013).

ii. Lower educational status, in general, the head of household has less than four years of schooling, and less than three percent of the total population has a training outside the high school (World Bank in Agostini, Brown \& Roman, 2008). This happens because they are very difficult to access the education (Eversole \&Cimadamore, 2005). Low skills and education have an impact on the scale of income, employment, health, housing and other poverty indices (Henson.et.al in Cornell, 2006). 
iii. Slums or Poor environmental conditions, has affected by climate change, all of which affect the resilience of the foods that cause them to experience hunger. They also lost their traditional lands and livelihoods as a result of the damaged environment (Clarke, 2001; Macchi.eds 2008; Gigler, 2009; Davis, 2010; FAO, 2010; Hall \& Petranos 2011; IWGA, 2015; Dhir, 2015; Patrinos, 2017).

Poverty is forded by indigenous peoples, not only caused by internal factors are the limited skills (life skills), beside that the external factor also has a big impact such a geographically where the location of settlements from indigenous peoples are classified as a minimal access or remote. (Sudirman, 2018; Suradi.et.al, 2007, 2013); there are injustices and discrimination in the social, economic, and political fields (May \& Aikman, 2003; Freeman \& Fox, 2005; Agostini, Brown \& Roman, 2008; Gigler, 2009; Burridge, Whalan \& Vaughan, 2012; Gordon \& White, 2014).

Indigenous peoples become victims of large-scale development impacts (Memmott, Stacy, Chambers \& Keys, 2001); and cannot escape being a victim of ethnocide from government policies that seek to promote a uniform national culture, and are affected by the deterioration of social order and political stability (Clarke, 2001). They are evicted or rejected when accessing the natural resources for survival, give the stereotype of the "backward", "uncivilized", "primitive" and "uncivilized" or "pillory state" (ACHPR, 2006; UN, 2009).

\section{Role of Social Workers}

At the international level, the social work profession occupies a very important position on the concept of human rights (Reichert, 2001); and therefore the social worker defined as human rights workers (Calma, 2008). Social work based human rights is important in all work performed, but perhaps more so for indigenous peoples. They are generally low in a number of social indicators, so they need to start from a base where they do not have the same chance of living as non-indigenous peoples (Calma, 2008).

The Code of Ethics asserts the main principles and values of social work are human dignity and social justice. Self-esteem or human dignity means that social workers respect the dignity that inherits in everyone, and respect for human rights that assert in the United Nations Universal Declaration of Human Rights. Social justice includes the satisfaction of basic needs; fair access to services and potential development, as well as the recognition of individuals and community rights (Calma, 2008).

As a human rights worker, social worker with indigenous peoples need to understand the United Nations Declaration on the Rights of Indigenous Peoples (UNDRIP), which was proclaimed the United Nations in 2007. The UNDRIP is seen and placed by the member of countries as international law, and as a framework for empowering indigenous peoples. This becomes important because in UNDRIP the rights of indigenous peoples, including women and children, on them are arranged clearly and unequivocally - were duly gain recognition, respect, and protection by the state.

The role that can be done be performed by social workers in helping indigenous peoples to faced the problems are:

i. Social workers who work in advocacy involved in the protection and defense of indigenous peoples. Rights of indigenous peoples need defense and protection, such as rights to land, natural resources, civil and political rights, security, justice and non-discrimination. in these advocates role, social workers will deal and face with the state (bureaucracy), and the stakeholders who have power in order to distribute the power to indigenous peoples.

ii. Facilitators, social workers help indigenous peoples to access social services and basic social needs. Such as services: education, health care, clean water, housing, income and social security. The sources of these services not only on government institutions but also in the business community, NGOs and the public community. The role of the faciilitator, social 
workers will deal with the state (bureaucracy), and stakeholders who have resources in order to distribute the proposal to indigenous peoples.

iii. Educators, social workers are involved in the process of change of indigenous peoples through capacity building. On behalf developing of this capacity, social learn together to understand the problems, potential, and their needs; so that they are able to make a plan, make rational decisions, and carry out productive activities. Relating to self-determination, indigenous peoples have the ability to control programs that have a direct impact on them, and participate directly in the social, cultural, environmental and political (developed from Calma, 2008).

These various roles will be implemented optimally when social workers have adequate knowledge, practical experience, and demonstrated their competence. According to the Aboriginal Community Social Work (2013), the competence of social worker with indigenous peoples, as follows:

i. Traditional knowledge lies in the native culture.

ii. Knowledge and understanding of the native language associated with the context, values, and relationships.

iii. Knowledge of the values in practice in community service: reciprocity, interdependence, interrelation, and participation.

iv. Awareness of the knowledge and expertise that is not appropriate, or contrary to the theory and social work approach.

v. Participation in cultural activities.

vi. Knowledge of various levels and kinship systems.

vii. Knowledge and understanding of the theoretical framework for social work with indigenous peoples.

viii. Knowledge of psychology and religion, social theory, policy and legal, education and research.

ix. Quick response to various services that indigenous peoples' needs.

Regard to culture, according to Weafer (1999) it necessary to include cultural issues as an important factor in the process of assistance in social work with indigenous peoples. According to the literature, now social work has moved from cultural sensitivity (cultural sensitivity) to cultural competence (Cultural competence), which is an ability to integrate cultural knowledge and sensitivity with the skills for the help process that is more effective and culturally appropriate (see NASW, 2001).

The importance of this cultural competence put forward by Vinkle (2012), throughout the education that followed in the field of social work, had learned about the importance of cultural competence as it relates to the profession of helping and working with Aboriginal communities. It was stated, when social work practice, they recognize that cultural competence in working with Aboriginal communities is a necessity. It will be able to explain that the actions taken by the social workers are aimed to achieving the goals.

\section{Conclusion}

Indigenous peoples in any country as a minority, second-class citizens and based on this situation, they have to face a lot of limitation for survival. They live in isolation in accordance with social, cultural and geographical, victims of injustice, discrimination, and deprivation of land and natural resources; causing them y to be poor in the category of extreme poverty or poverty cronies.

The presence of a social worker is highly anticipated by indigenous peoples to help find solutions to the problems they face. The role of social workers as an advocate, facilitator, and educator; expected to be able to bring the country and stakeholders to provide recognition, respect, and protection of their human rights. As like as other citizens, indigenous peoples have easy access to various of services such as education, health, water, housing, land, and capital; so that their standard of living will get better. 


\section{References}

Abdullah.J, Borhan.MA, \& Ahmad.CB, (2015). Orang Asli Resettlement in Urban Environment at Bukit Lanjan, Selangor, Malaysia, Procedia - Social and Behavioral Sciences 201 (2015) 71-79.

Aboriginal Community Social Work, (2013). the Indigenous Social Work and Social Work Practice Competence, https://acsw.in1touch.org/../ RPT_ACSWIndigenous SWStan ... [05.07.2018.

African Commission on Human and Peoples' Rights (ACHPR) and the International Work Group for Indigenous Affair (IWGA) (2006). Indigenous Peoples In Africa: The Forgotten Peoples? ACHPR, The Gambia.

African Commission on Human and Peoples' Rights (ACHPR) (2006). Indigenous Peoples In Africa: The Forgotten Peoples? ACHPR, The Gambia.

Asian DevelopmentBank (ADB), (2002). the Indigenous Peoples / Enich Minorities and Poverty Reduction, Regional Report, Manila, Philippines,

Agostini, Brown \& Roman, (2008). Etimating Poverty for Indigenous Groups in Chile by Macthing Census and Survey Data, Willain David Institute.

Asian's Indigenous Peoles Act (AIPP), the International Work Group for Indgeous Affairs (IWGIA) and Forum Asia (2017). the Asian's Indigenous Peoples, Chiang Mai Thailand.

National Indigenous Peoples' Alliance (AMAN) and the Asian Indigenous People Act (AIPP), (2017). the Situation of Human Rights of Indigenous People in Indonesia, www.aman.or.cid [06/07/2018].

Amnesty International / AI, (2014). Indigenous Peoples' Long Struggle to Defend Their Right in the Americas, Landon: Amnesty International Publications International Secretariat

Anderson.RB, Schneider.B and Kayseas.B (2008). Indigenous Peoples' Land And Resource Rights, National Center for First Nations Governance, West Vancouver, Canada.

Arizona.Y, (2016). Understanding Indigenous Peoples: Evoluasionis approach versus Pluralist, paper presented at the Focus Group Discussion (FGD) Constitutional Protection / https: // yancearizona. files. wordpress.com/. pdf [10/01/2018].

Astrid.B \& Girard.F, (2008). "Sexuality, Health, and Human Rights: Self-Identified Priorities of Indigenous Women in Peru." Gender \& Development 16 (2): 247-256.

Agostini, Brown \& Roman, (2008). Etimating Poverty for Indigenous Groups in Chile by Macthing Census and Survey Data, Willain David Institute.

Bailie.RS, \& Wayte.KJ (2006). Housing and Health in Indigenous Communities: Key Issues for Housing and Health Improvement in Remote Aboriginal and Torres Strait Islander Communities, Aust. J. Rural Health (2006) 14, 178-183. DOI: 10.1111 / j.14401584.2006.00804.x.

Berkes.F, Colding.J \& Folke.C, (2000). Rediscovery of Traditional Ecological Knowledge As Adaptive Management, Ecological Applications, 10 (5), 2000, pp. 1251-1262, 02000 by the Ecological Society of America.

Burridge, Whalan and Vaughan, (2012). Indigenous Education A Learning Journey for Teachers, Schools and Communitie, transgressions: And Education Cultural Studies, Volume 86, Rotterdam Publisher Sense.

Buzaale.OOB Baabwe.ABB, and Baana. ANNK (2007). Chronic poverty: an introduction, Cronic Poverty Research Center, Policy breif, https://www.odi.org/.../1156-chronic-povertyintroduction- [05/07/2018].

Calma.T (2008). The Role Of Social Workers As Human Rights Workers With Indigenous People And Communities, Social Work Orientation Week Seminar, Australian Catholic University, https: // www.humanrights.gov.au/[04/19/2017].

Canedo.AP, (2017). Closing the Gap in Indigenous Mexico: A Comparative Report on Multidimensional Poverty Estimates from anEthnic Perspective, https://ecommons.cornell.edu/handle/1813/54756 [06/20/2018].

Castillo.BH (2004). Indigenous Peoples In Isolation In The Peruvian Amazon Survival And Their Struggle For Freedom, International Work Group for Indigenous Affairs (IWGIA), Denmark.

Christie.R, (2015). the Millennium Development Goals (MDGs) And Indigenous Peoples' Literacy In Cambodia: Erosion Of Sovereignty?, Journal Of The Association For The Study Of Ethnicity And Nationalism, Doi: 10.1111 / Nana.12096. 
Coates.KS (2004). A Global History Of Indigenous Peoples Struggle And Survival, Palgrave Macmillan, New York, NY 10010

Cornell.S (2006). Indigenous Peoples, Poverty and Self-Determination in Australia, New Zealand, Canada and the United States, Udall Center for Studies in Public Policy The University of Arizona, http://nni.arizona.edu [03/15/2018].

Clarke. G, (2001). From ethnocide to Ethnodevelopment? Ethnic Minorities and Indigenous Peoples in Southeast Asia, Third World Quarterly, 22(3), 413-436.

Davis, SH, (2010). Indigenous Peoples and Climate change.the International Indigenous Policy Journal, 1 (1). Retrieved from:http://ir.lib.uwo.ca/iipj/vol1/iss1/2, DOI: 10.18584 / iipj.2010.1.1.2.

Dhir. RK, (2015). the Indigenous Peoples in the World of Work in Asia and the Pacific: A Status Report, Geneva: International Labor Organization (ILO).

Downing.Th.E, Moles.J, McIntosh.I, Downin.CG (2002). Indigenous Peoples and Mining Encounters: Strategies and Tactics, England: International Institute for Environment and Development (IIED).

Eversole. R, Mcneish. JA \& Cimadamore. AD (ed), (2005). Indigenous Peoples and Poverty an International Perspective, CROP - International Studies in Poverty Research, New York.

Food Organization of the United Nations (FAO), in 2010, the FAO Policy Oon Indigenous and Tribal Peoples, FAO - Rome, Italy.

Fekadu.B, (2007). The Role Of Customary Institutions In Managing Conflict On Grazing Land: A Case Study From Mieso District, Eastern Ethiopia, Institutional Change In Agriculture And Natural Resources, Berlin, Humboldt-Universität.

Feiring.B (2008). Including Indgenous Peoples in Poverty Reduction Strategies: A Guide Prictice based on Exeperrience from Cambodia, Cameroon and Nepal, the International labor Organization.

Fekadu.B, (2007). The Role Of Customary Institutions In Managing Conflict On Grazing Land: A Case Study From Mieso District, Eastern Ethiopia, Institutional Change In Agriculture And Natural Resources, Berlin, Humboldt-Universität.

Gigler. B, S, (2009). Poverty, Inequality and Human Development of Indigenous Peoples In Bolivia, 2009, Working Paper Series No. 17, Center for Latin America Studies, Georgetown University.

Gordon.CE and White.JP, (2014). Indigenous Educational Attainment in Canada, Indigenous Educational Attainment in Canada.The International Indigenous Policy Journal, 5 (3) .Retrieved from:http://ir.lib.uwo.ca/iipj/vol5/iss3/6 DOI: 10.18584 / iipj.2014.5.3.6

Hampton.R, and Toombs.M., (2013). Culture, Identity and Indigenous Australian people. In Ron Hampton and Maree Toombs (Ed.), Indigenous Australians and health: the wombats in the room (pp. 3-23) South Melbourne, VIC, Australia: Oxford University Press.

Hall. G. \& Patrinos.HA (ed), (2011). Indigenous Peoples, Poverty and Development, the World Bank.

Hall.G \& Patrinos.H, (2015). Ch. 9 Conclusion: Towards a Better Future for the World "s Indigenous, World Bank,https://www.researchgate.net/.../297445310_Indigenous_Peo ...[06/07/2018]

Heineke.C and Edward.S, (2012). Health Inequities of Indigenous Peoples and Ethnic and Cultural Minorities - Turning the Tide Through The Post-2015 Development Framework,

Hulme.D, Moore, K \& W Shepherd.A, (2001). Chronic Poverty: Meanings And Analytical Frameworks, https://www.ssrn.com/abstract=1754546 [10/07/2018].

International Amnesty (2014). Violence Against Indigenous Women and Girl in Canada: Summary of Amnesty Internationals Concerns and Call to Action, February, 2014.

Internationa Asssosation for Impact Assessment (IAIA), (2012). Respecting Indigenous Peoples and Traditional Knowledge: International Best Practice Principles, Special Publication Series No. 9, 2012,http://www.iaia.org/best-practice.php [02/12/2018].

Intenational Labor Organization (ILO), (2011). Unlocking Indigenous People's Potential for Sustainable Rural Development, polcy breif, ILO, Geneva.

International Amnesty, (2014). Violence Against Indigenous Women and Girl in Canada: Summary of Amnesty Internationals Concerns and Call to Action, February, 2014.

Islam.MR and Sheikh.MA (2010). Cultural and socio-economic factors in health, health services and prevention for indigenous people, Antrocom Online Journal of Anthropology 2010, vol. 6, no. 2, ISSN 1973-2880. 
Islam.F \& Carlsen.J, (2015). the Indigenous Communities, Tourism Development and Poverty Extreem Allevation in Rural Bangladesh, SAGE, DOI: 10.3567 / te 2014.0456.

International Work Group for Indigenous Affairs (IWGIA), (2015). The Indigenous World 2015, IWGIA, Copenhagen, Denmark.

Jha.V \& Jha.A, (2011) Traditional Knowledge on Disaster Management: A Preliminary Study of the Lapcha Community of Sikkim, India, Indian Journal of Traditional Knowledge, 10 (1), 173-182.

Jimenez, W, and M, Vera. (2010). Indigenous Population and Differences in Access to Primary Education in Bolivia. Ottowa: FOCAL: Canadian Foundation for the Americas.

Kleden.EO (2007). Evolution Struggle of Ideas "Indigenous Peoples 'Rights" in the national and international sphere, paper presented at the Advanced Training "Rights of Indigenous Peoples (Indigenous Peoples' Rights) for Lecturers of human rights in Indonesia, Yogyakarta, 21 to 24 August, 2007.

Kuokkanen.R, (2012). Self-Determination and IndigenousWomen's Rights at the Intersection of International Human Rights, Human Rights Quarterly 34 (2012) 225-250, The Johns Hopkins University Press.

Loewenberg, S (2010). "The Plight of Mexico's Indigenous Women." Lancet 375 (9727): 1680-1682.

Macchi. M. eds, 2008, Indigenous Peoples And Traditional And Climate Change, 2008, Issues Paper, International Union for Conservation of Nature and Natural Resources (IUCN), Danièle PerrotMaître.

Mauro.F \& Hardison. P. D, (2000). Traditional Knowledge of Indigenous and Local Communities: International Debate and Policy Initiatives, Ecological Applications · Vol. 10, No. 5 (Oct., 2000), pp. 1263-1269, DOI: 10.1890 / 1051-0761 (2000) 010.2.0.CO.2.

May.S and Aikman.S (2003). Indigenous Education: Addressing Current Issues and Developments, Comparative Education, Vol. 39, No. 2, Special Number (27): Indigenous Education: New Possibilities, http://www.jstor.org/ stable / 3099875.

Melendes.AP \& Loenzo.AMC, (2014). Woman Interpreneur in Indigenous Communities: The Case of Tiquiopaya (Bolivia), the University of Malaga.

Memmott.P.et.al, (2001). Violence in Indgenous Peoples, In Association with Aboriginal, Environments Research Center, University of Queensland.

Morley.S, (2015). What Work in Community-maneged Effetive Indigenous Programs and Organizations, Australian Stitue of Family Studies.

National Association of Socail Workers (NASW), in (2001). Standard Indicators for Cultural Compeence in Social Work Practice, Washington DC.

Patrinos, (2017). Indigenous Peoples, Poverty and Development: Global Overview, World Bank.

Popova. U (2013). Conservation, Traditional Knowledge, and Indigenous Peoples, Published Online 9 August 2013 American Behavioral Scientist, DOI: 10.1177 / 0002764213495043.

Reading.C and Wein.F (2013). Health Inequalities and Social Healtih Diterminants of Aboriginal Peoples, National Collaborating Center for Health Aborinal, Australia.

Reicahert.E, (2001). Placing Human Rights at the Center of the Social Work Profession, the Journal of Intergroup Relations, Vol. XXVIII, No.1, Spring.

Rumbach.A, \& Foley.D, (2014). Indigenous Institutions and Their Role in Disaster Risk Reduction and Resilience: Evidence from the 2009 Tsunami in American Samoa, Ecology and Society 19 (1): 19. http: // dx.doi.org/10.5751/ES-06189-190119.

Rutten.R, (2016). Introduction: Indigenous People and Contested Access to Land in the Philippines and Indonesia,KASARINLAN VOL. 30, NO. 2 and VOL. 31, NO. 1 2015/2016.

Sobrevila.C (2008). The Role of Indigenous Peoples in Biodiversity Conservation The Natural but Often Forgotten Partners, the World Bank, Washingto, USA.

Sudirman, (2018). Preliminary Assessment Report and Feasibility Study on Remote Indigenous Communities Empowerment Melawi District, West Kalimantan.

United Nations (UN), (2012). Guiding Principles on Extreme Poverty and Human Rights, UN.

United Nations (UN), (2004). The Concept Of Indigenous Peoples, Workshop on Data Collection and disaggregation for Indigenous Peoples, 19-21 January 2004, New York.

United Nations Declaration on the Rights of Indigenous People (UNDRIP) (2007). The Declaration on the Rights of Indigenous Peoples, United Nations, New York. 
United Nations Development Programs (UNDP) (2010). UNDP and Indigenous Peoples: A Practice Note on EngagementUNDP www.undp.org/... / .../ UNDP and Indigenous Peoples ... [10.07.2018].

United Nations Development Programs (UNDP) (2017). UNDP Social and Environmental Standards: Standard

Indigenous Peoples,https://intranet.undp.org/unit/bpps/DI/SES_Toolkit/default.aspx. [07/02/2018].

United Nations Development Programs (UNDP) (2015). Implementing the UN Declaration on the Rights of Indigenous Peoples Handbook for Parliamentarians No. 23, New Yort, USA.

United Nations (UN) (2009). Workshop On Data Collection And disaggregation for Indigenous Peoples, New York: UN.

United Nation (UN) (2010). Indigenous Peoples Make Up One-Third of the World's Poorest And Suffer Alarming Conditions In All Countries, http://www.un.org/esa/ socdev / UNPFII / documents / SOWIP / press\% 20package / sowip-press-package-en.pdf [16/07/2018]

United Nation (UN) (2010). Indigenous Peoples Make Up One-Third of the World's Poorest And Suffer Alarming Conditions In All Countries, http://www.un.org/esa/ socdev / UNPFII / documents / SOWIP / press\% 20package / sowip-press-package-en.pdf [16/07/2018]

United Nations Children's Found (UNICEF) (2003). Tea Ensuring Right of Indigenous Children, UNICEF, Italy.

Valeggia.CR, and Snodgrass.JJ (2015). The Health of Indigenous Peoples Annu. Rev. Anthropol. 2015. 44: 117-35, The Annual Review of Anthropology is online at anthro.annualreviews.org, doi: 10.1146 / annurev-anthro-102214-013831.

Velasquez.I (2007). Extreme Poverty: Vulnerability and Coping Strategies Among Indigenous People in Rural Areas of Bolivia, https://cuvillier.de/de/shop/ publications / 1610 [15/07/2018].

Vera.DED (2007). Indigenous Peoples in the Philippines: A Country Case Study Presented at the Nuclear Regulator Interface Protocol (RNIP) Regional Assembly Hanoi, Vietnam August 2026, 2007.

Vinkle.E, (2012). Cultural Competency - Working With Aboriginal Peoples: A non-Native Perspective, Native Social Work JournalVol 8, pp. 129-142.

Walter.M, (1999). Chapter 5: Aboriginality, Poverty and Health-Exploring the Connections, https://www.lowitja.org.au/ aboriginality-poverty-and-health-... [06.07.2018].

Walker.RS, Hamilton.MJ \& Groth.AA, (2014). Remote Sensing And Conservation Of Isolated Indigenous Villages in Amazonia, .R. Soc. open sci.1: 140246. http://dx.doi.org/10.1098/rsos.140246

Zukang. S (2009). Foreword to the State of the World's Indigenous Peoples, Economic and Social Affairs, United Nations. 